\title{
Lecturing with Animations on the Measuring Experiment for the Mechanical Equivalent of the Heat
}

\author{
Nigmet KOKLU*1, Dundar YENER ${ }^{2}$, Hamdi Sukur KILIC ${ }^{3}$
}

\author{
Accepted : 28/12/2017 Published: 31/12/2017
}

DOI: 10.18100/ijamec.2017436079

\begin{abstract}
In this study, animations were used to get for students to better and easier undertand to comprehend the topic of "measurement of the mechanical equivalent of the heat," described and conducted in the general physics laboratory. The descriptions related to the experiment and the topic were composed in the form of animation. The measuring solution of the mechanical equivalent of the structure and heat of the calorimeter was presented also by animations. Thus, it is desirable to provide students with an entertaining opportunity to learn more about the topic as well as to keep alive the interest of the students all the way. The materials along with their shapes to be used in the comparison experiment of the specific heats were shown as animations. The animation communicates with you in which steps should be followed in order to conduct the experiments properly. Additionally, the related literature on conceptual errors has been investigated in order to prevent possible misconceptions about this topic. In this way, it is aimed that the students will comprehend the experiment more easily.
\end{abstract}

Keywords: Animation, Specific heat, Physics laboratory, Mechanical equivalent of the heat, Relationship between calories and joules.

\section{Introduction}

In the computer-aided multimedia learning environments are animations which are one of the most commonly used multimedia technologies. "Animation" is a Latin word, its meaning is "revive" [1]. Animation according to Laybourne (1998) is a live, striped, detailed production of the computer images. Animations show according to circumstances that some things are coming in sight, some things are disappearing and shapes or colours are getting changed. These changes may occure in the graphics as well as in the cartoons and pictures. The pictures and cartoons will not be named "animation" when they are not moving and showing no alteration. Because animations should not be moving constantly, should they stay in motion permanently [2]. According to Burke et al. (1998), animation is a revived moving picture that represents the motion of the drawn or revived object. In this definition, three main features of the animation are remarkable. According to these features, animation is a (1) picture type of the visual presentations, (2) movement that describes certain motions, (3) moving object artificially is imagined by drawings or other imitation methods. The consciously utilization of the animations improves the comprehension degree of the students. When the computer animations should be a part of an applied strategy of the education, they may also be used as a feedback for the students [3-5].

Teachers who have chosen to teach the traditional lecturing methods are causing the following students to be bored and lost their attentions in a very short time. Nevertheless, the lesson provides a significant contribution to focus students' attention on the lesson topic and eliminate the boredom when lectures are made

\footnotetext{
1 Selcuk University, Technical Sciences Vocational High School, Konya/TURKEY

${ }^{2}$ Abant Izzet Baysal Univerysity, Faculty of Education, Bolu,TURKEY

${ }^{3}$ Selcuk University, Faculty of Science, Department of Physics, Konya, TURKEY

*Corresponding Author: nkoklu@selcuk.edu.tr
}

impressive with spectacular animations [6]. In the study performed by Marshall and Shipman; unlike the texts, animations present some scientific events in a visual, interactive and multidimensional manner. Animations have brought a new concept to the lecturing in the science field with their interesting animated shows and have enriched students' imagination worlds. Through animations, many concepts in the teaching of the scientific facts can be explained in a way of attracting the students. In the science lecturing, observable alterations in the material (e.g. colour change, smell, boiling) are explained in two ways. The first type of lecturing is at the laboratory level and the second type is at the microscopic level. Lectures at the microscopic level are either explained by symbols and signs qualitatively, or mathematics quantitatively [7].

Ebenezer (2001) has stated, according to the results of his study, that the animation effects the students positively in their comprehending and discovering the concepts and learning meaningful. It is especially recommended that the animation method must be used in teaching and comprehending of many abstract concepts in science education so that the attention of the students may be caught. Moreover, it was stated that the lecturing with animations has a positive effect on the students according to other teaching methods $[8,9]$.

\section{The Object and Importance of the Study}

This study was aimed and performed to prepare an animated lecture material for facilitating the comprehending of the topic "measurement of the mechanical equivalent of the heat" by the students more quickly, easily and comfy and for facilitating the education by minimizing the misconceptions where the laboratory is not available. Thus, it makes also possible to visualize the scientific events on the computer, which are difficult to comprehend, dangerous or expensive to implement in the laboratory, or may take a long time to be observed. At the same time, it was aimed to consolidate the lesson topic by using 
animations in different examples related to the topic.

\section{Application and Design}

The ratio of the energy amount to the amount of the generated heat remains always constant, if any energy is converted to the heat energy whatever the species. This constant rate is denoted by " $J$ " and is known as the mechanical equivalent of the heat. In our experiment, studies were conducted to measure the mechanical equivalent of the heat, and the definitions and problems related to the topic were solved through animation.

When the animations were constituted, attention has been taken that the animation is linked to the topic lectured and every animation in the study attracts the attention of the students. In this way, students were allowed to enjoy the topic. Care was taken to ensure that the colours and movements used in the animation are in a consistent shape on the screen that does not strain the eyes and the view is clear. In the animations, the natural tones and shapes appropriate to the age level of the students were used. The animations were visual, audio and practical constituted. Care has been taken to make it possible that the font is readable in terms of type, colour, size, and is easy to perceive the motion.

Each animation includes the forward and backward keys to enable the desired division transition. At the same time, very long texts were not preferred particularly. Thus, the information to be given becomes more noticeable [10].

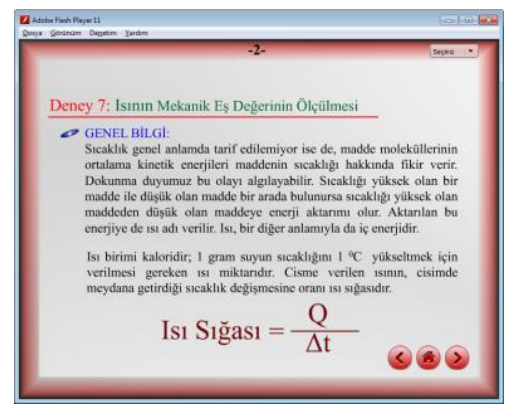

a) Definition of the heat and heat capacity formula

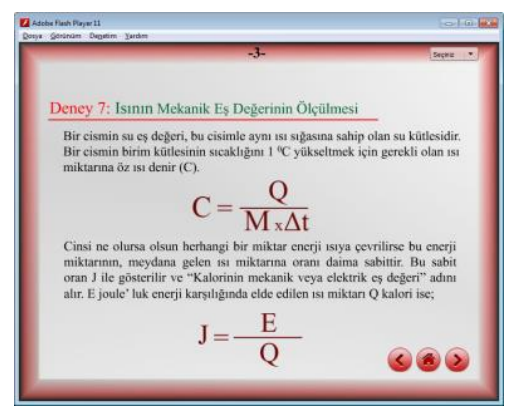

b) Specific heat and mechanical or electrical equivalent of the heat

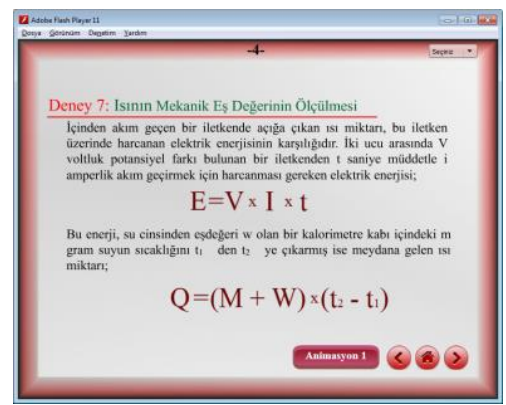

c) Obtaining of formulas

Fig 1. Definitions and formulas for measuring the mechanical equivalent of the heat
Fig. 1.a) gives the definition of the heat and its unit, the definition of the heat capacity and its formula. The experiment will be here easier to comprehend by remembering the knowledge that students have learned in the past. In the animation given in Fig. 1.b), the definition of the water equivalent of an object, the definition and formula of the specific heat, the definition and formula of the mechanical equivalent of the heat were given so that the subject can be better comprehended and the basic information can be reproduced. It was intended to visualize the topic about formulas of the electrical energy and the heat amount its equivalent is $\mathrm{W}$ for water that increases the temperature of $m$ grams of water from $t 1$ to $\mathrm{t} 2$ in the calorimeter vessel so that the students learn the topic more easily and keep it longer in their memory as animated in Fig. 1.c).

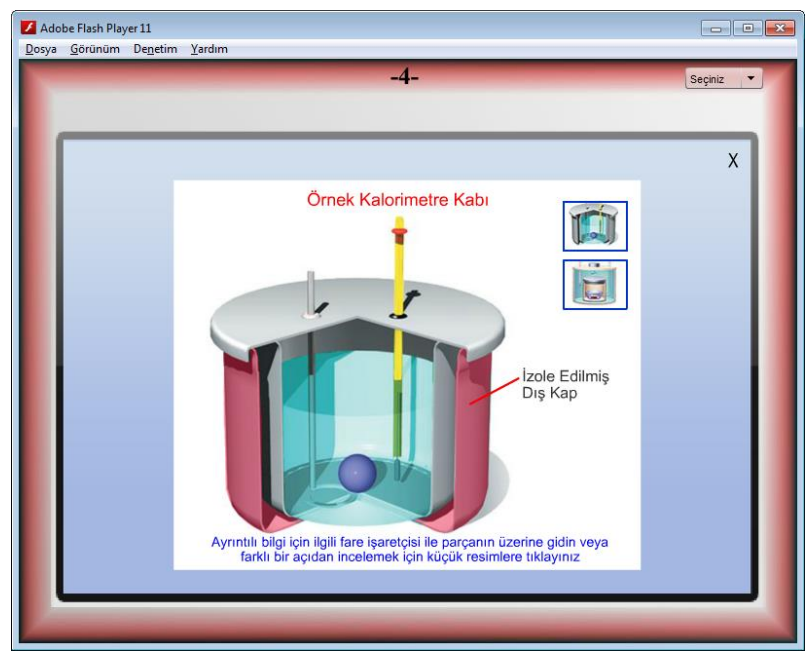

Fig. 2. Animation for the example calorimeter vessel

In Fig. 2, the parts of the calorimeter vessel are shown when the mouse cursor goes over the parts of the calorimeter vessel. These are: Thermally insulated vessel, inner vessel, cover, thermometer, mixer and water.

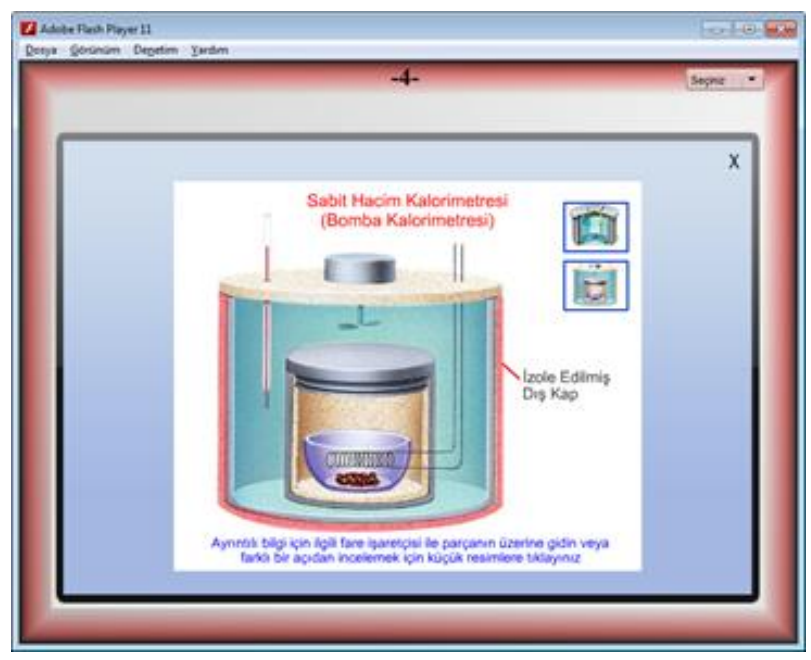

Fig. 3. Animation for the example constant volume calorimeter

In Fig. 3, an animation is given for the constant volume calorimeter. In this animation, the names of the parts are shown when small pieces in the constant volume calorimeter are clicked. These are: Thermometer, mixer, ignition cable, water, thermally insulated outer vessel, high pressure oxygen, steel vessel and ignition wire. It is quoted and edited from the source specified in the design of the animations in Fig.s 2 and 3 [11]. 


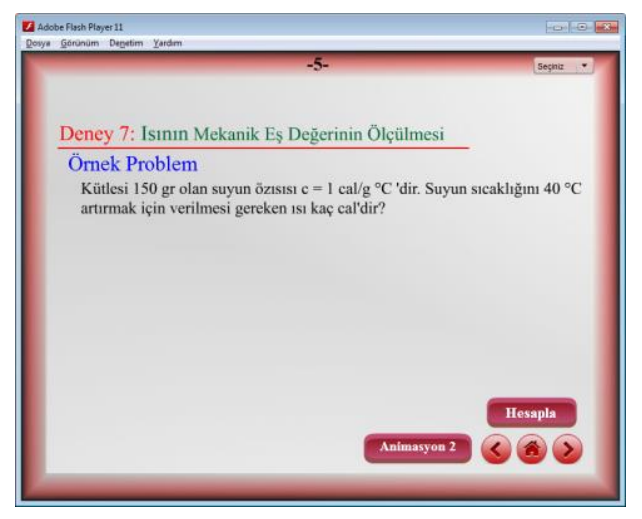

Fig. 4. An example for measurement to mechanical equivalent of the heat

In Fig. 4, a place is given to solve problem in the animation to better comprehend the experiment and to increase the memorability. In our problem was asked how many calories are required to increase $40^{\circ} \mathrm{C}$ degrees of the temperature of the 150 grams water. In the problem was the amount of the specific heat given as $1 \mathrm{cal} / \mathrm{g} .{ }^{\circ} \mathrm{C}$ degree.

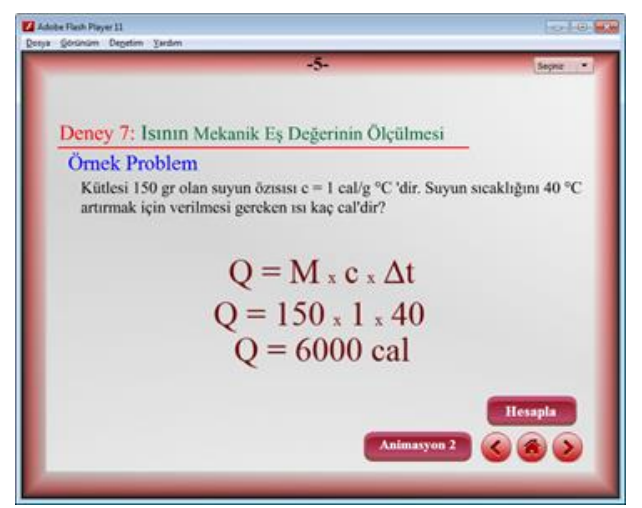

Fig. 5. Solution of the problem about measuring the mechanical equivalent of the heat

Fig. 5 gives the solution of the problem in Fig. 4. Therefore, it is desirable to provide students with an entertaining opportunity to learn more about the topic and to keep alive their interest to the lesson lectured.

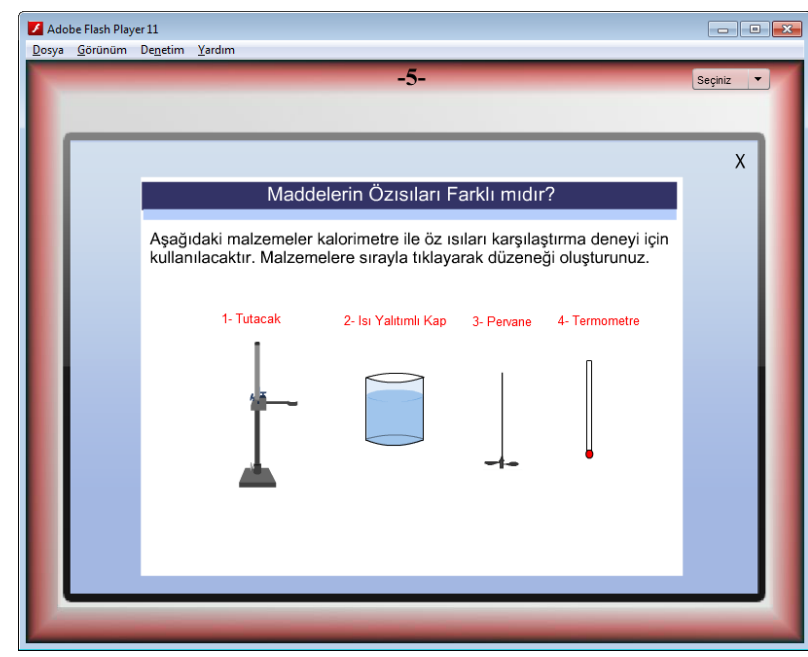

Fig. 6. Animation about the specific heat of the substance

In Fig. 6 are shown the calorimeter and the pictures of the materials used in the specific heat comparison experiment. These are: Holder, thermally insulated vessel, propeller and thermometer. The animation communicates you which steps should be followed in order to be able to conduct the experiment properly.

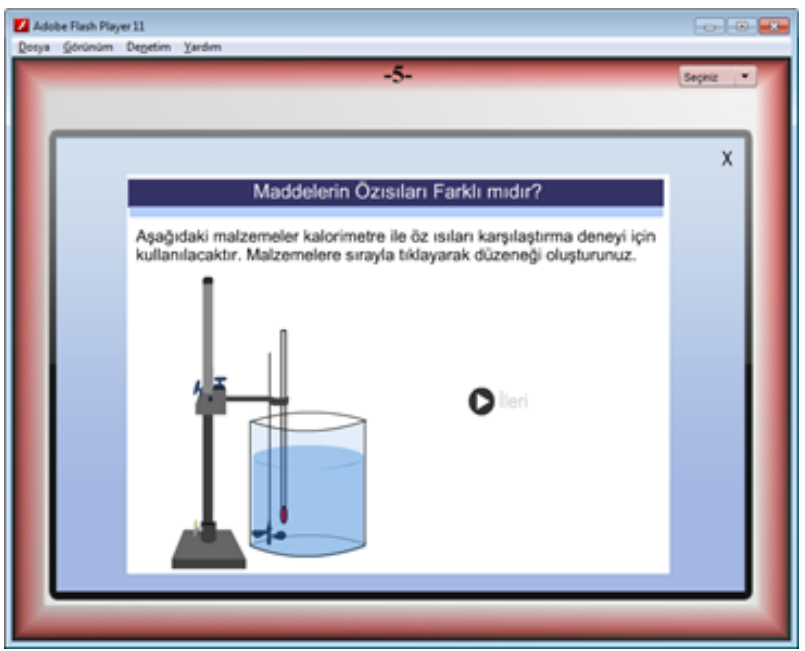

Fig. 7. Preparation of the calorimeter vessel setting

Fig. 7 shows how to place and organize the each apparatuses required for the preparation of the calorimeter vessel setting. In this animation, the calorimeter is built up in Fig. 7 by clicking on the header, thermally insulated vessel, propeller and thermometer apparatus given in Fig. 6. Student even may go directly to the next animation screen by pressing the "forward" key located in this animation.

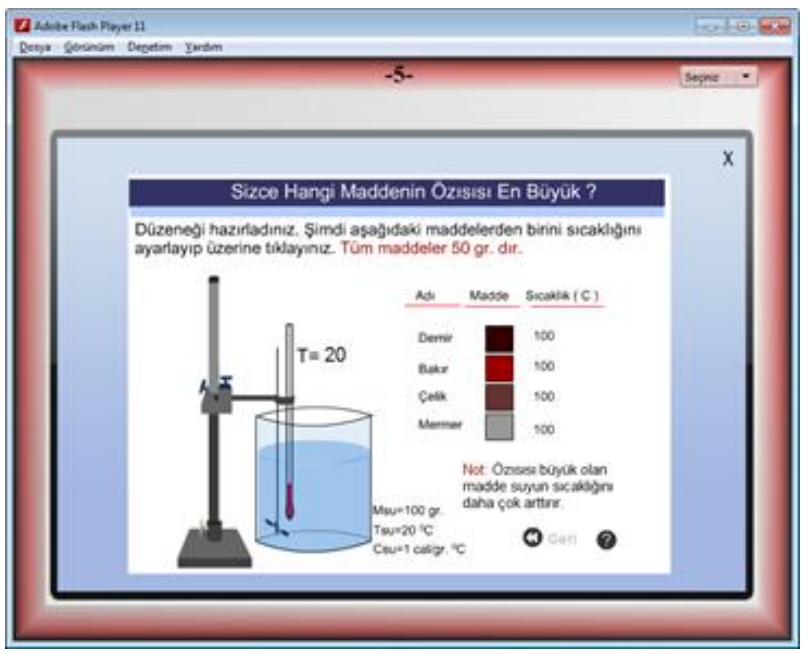

Fig. 8. Specific heat test setting for the different substances

After preparation of the experiment setting, the iron, copper, steel and marble materials, each having a weight of 50 grams and $100^{\circ} \mathrm{C}$ temperature, were poured into the water with a temperature of $20^{\circ} \mathrm{C}$, respectively. Then the temperature differences that they caused in the water are calculated. In this animation, it was also noticed that the material with a higher specific heat increases the temperature of the water more than lower one and the specific heat of water given as $1 \mathrm{cal} / \mathrm{g}{ }^{\circ} \mathrm{C}$. 


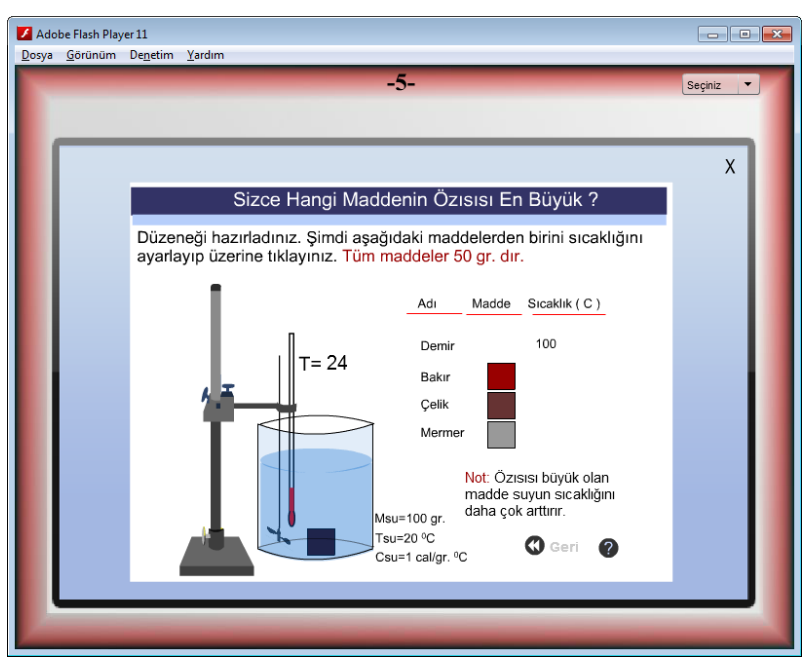

Fig. 9. Heat exchange in the calorimeter vessel of the iron at $100^{\circ} \mathrm{C}$ degrees

By clicking on the setting prepared in Fig. 9, $50 \mathrm{~g}$ of iron at $100^{\circ} \mathrm{C}$ degrees was placed in the calorimeter vessel and then observed that the temperature of the water was increased from $20^{\circ} \mathrm{C}$ to $24^{\circ} \mathrm{C}$ degrees.

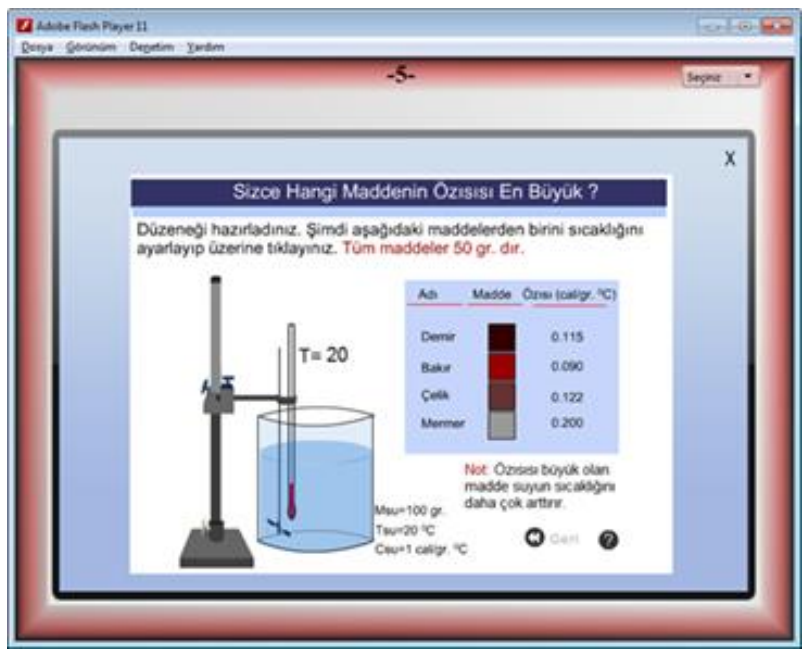

Fig. 10. Specific heat values of the different substances

In Fig. 10, the experiment was repeated also for the copper, steel, marble substances, respectively. When you click the question mark on the animation, information about the specific heats of the iron, copper, steel and marble substances are available andthese values are given to be $0,115 \mathrm{cal} / \mathrm{g}{ }^{\circ} \mathrm{C}, 0,090 \mathrm{cal} / \mathrm{g}{ }^{\circ} \mathrm{C}, 0,122 \mathrm{cal} / \mathrm{g}$ ${ }^{\circ} \mathrm{C}$ and $0,200 \mathrm{cal} / \mathrm{g}{ }^{\circ} \mathrm{C}$, respectively. At the end of calculations, it was observed that the material with a higher specific heat increases the temperature of the water more than orther lowers. It is quoted and edited from the source specified in the design of the animation in Fig. 10 [12].

\section{Results and Suggestions}

Animations are suitable for demonstration of the subjects that require an application [13]. Animations may be used by transferring them into the classroom environment to demonstrate and model phenomena and events that cannot be shown or applied in the classroom conditions. In addition, animations appeal to multiple sensory organs with dimensions of movement, colour and sound, making learning easier and providing students with a sense of liveliness and concrete and lasting learning $[14,15]$.
Considering the students' point of view on the animations, it is communicable that the subject animated increases the motivation of the students, makes the learning more alive, the students develop the thinking power, helps the comprehending of the lesson topics, increases the interest of the physics lessons and decreases the misconceptions about the topics. It has also been observed to facilitate the understanding of complex information or events by bringing the flow of information to be present into proper order and arrangement.

In order to increase the achievement of science and physics education to the desired level, the lessons should be carried out with a laboratory support. Some experiments cannot be accomplished in the laboratory due to lack of laboratory or high cost of the related experiments. In such cases, it is considered that the application of the experiments by the students prepared with animations will increase the success and decrease the misconceptions in the lessons.

Computer laboratories are needed to use animation in the classroom. For this reason, schools not having computers need to be compensated for these shortcomings. For some difficult, expensive and dangerous experiments, the participants have emphasized that it is easier to animate the lesson topics and more useful to see the details of them. Teachers and students should be aware of the importance of animation in the science and physics education.

Some of the students participated in the study have stated that they have wanted to prepare these and similar materials themselves. The effect of the animation materials may be investigated regarding to the achievement, motivation, concept teaching and misconceptions of the students. It is suggested that the animated and student centered teaching methods like this are used in other units of the physics lesson.

\section{References}

[1] Foley , J., A., Van Dam, S. ve Feiner, J. (1990). Computer graphics principles and practice (2nd edt). New York, U.S.A: Addison - Wesley.

[2] Laybourne K. (1998). The animation book: a complete guide to animated film-making from flip-books to sound cartoons to 3-d animation. N.Y., USA: Three Rivers Press.

[3] Burke, K. A., Greenbowe, T. J. and Windschitl, M. A. (1998). Developing and using conceptual computer animations for chemistry instruction. Journal of Chemical Education, 75 (12), 1658-1661.

[4] Rieber, L.P. (1990a). Animation in computer-based instruction, Edcational Technology Research and Development, 38 (1),7786.

[5] Karaçöp, A. (2010). Öğrencilerin elektrokimya ve kimyasal bağlar ünitelerindeki konuları anlamalarına animasyon ve jigsaw tekniklerinin etkileri. Yayınlanmamış Doktora Tezi, Atatürk Üniversitesi Fen Bilimleri Enstitüsü, Erzurum.

[6] Çalıskan, S., (2002), Uzaktan eğitim web sitelerinde animasyon kullanımı, Açık ve Uzaktan Eğitim Sempozyumu, https://aof20.anadolu.edu.tr/bildiriler/Sabahattin_Caliskan.doc, 23-25 Mayıs, Eskişehir.

[7] Marshall, C.C., and Shipman, F.M., 1995, Spatial hypertext, Designing for change, Communications of the ACM, 38 8, 8897.

[8] Ebenezer, J. V., 2001, A hypermedia environment to explore and negotiate students conceptions animation of the solution process of table salt, Journal of Science Education and Technology, 10 1, 73-92. 
[9] Dalton, R.M., 2003, The development of students' mental models of chemical substances and processes at the molecular level, Unpublished PhD Thesis, University of Western Sydney, Australia.

[10] Köklü N., 2009, Elektrik konularının öğretiminde pedagojikanalojik modellerin öğrenci başarısına etkisi, Yükseklisans Tezi, Selçuk Üniversitesi Fen Bilimleri Enstitüsü, Ortaöğretim Fen ve Marematik Alanlar Eğitimi Anabilim Dalı, Fizik Öğretmenliği Programı, Konya.

[11] Anonymous, 2011, Simple calorimeter [online], Web adresi: http://resources.wwps.org/wwhs/tcarlsen/documents/cp\%20ph ysics/visual\%20concepts/110103\%20Calorimeter.swf, [Access Date: 10.11.2011].

[12] Karataşçı, M., 2014, Maddelerin özısıları farklı mıdır? [online], Web adresi: http://atanesa.atauni.edu.tr/NesneGor.aspx?NesneId=5649, [Erişim Tarihi: 09.07.2014].

[13] Quigley, E., Yu, Y., Huang, J., Lin, W., \& Fedkiw, R. (2017). Real-time Interactive Tree Animation. IEEE Transactions on Visualization and Computer Graphics.

[14] Liu, L. M., Li, W., \& Dai, J. J. (2017, August). Haptic technology and its application in education and learning. In Ubi-media Computing and Workshops (Ubi-Media), 2017 10th International Conference on (pp. 1-6). IEEE.

[15] Murakami, G. E., Hirata, D., Monteiro, M. A. A., Pinheiro, D. M., \& Germano, J. S. E. (2017), Proposal of a Learning Management System for Physics Education with the Inclusion of WebLab and Assessment of its Application., pp. 101-113, doi:10.17265/2162-5263/2017.02.005 